\title{
Analysis of Mathematic High Order Thinking Skills (HOTS) Problems Based on Cognitive Level Indicators on Bloom Taxonomy
}

\author{
Lia Amalia, a), Makmuri², b), Tian Abdul Aziz ${ }^{3, c)}$ \\ ${ }^{123}$ Universitas Negeri Jakarta, Rawamangun, Jakarta Timur \\ Email penulis: ${ }^{\text {a) }}$ amaliaalfath15@gmail.com, ${ }^{\text {b) }}$ makmuri@unj.ac.id, ${ }^{c}$ tian_azis@unj.ac.id
}

\begin{abstract}
This study aims to analyse the questions of high order thinking skills in the Statistics chapter in 2013 curriculum Mathematics textbook which are measured based on indicators of cognitive levels in Bloom's taxonomy. The object of this study is the questions in the Statistics chapter in the Mathematics textbook which is 3 questions. The question analysis technique is based on problem solving with details of competency standards, question indicators, HOTS indicators, Questions and Answer Keys.
\end{abstract}

Keywords: High Order Thinking Skills, Statistics, Bloom's Taxonomy

\begin{abstract}
Abstrak
Penelitian ini bertujuan untuk menganalisis soal-soal keterampilan berpikir tingkat tinggi pada bab Statistika pada buku teks Matematika Kurikulum 2013 yang diukur berdasarkan indikator tingkat kognitif dalam taksonomi Bloom. Objek penelitian ini adalah soal-soal pada bab Statistika pada buku teks Matematika yang berjumlah 3 soal. Teknik analisis soal berbasis pemecahan masalah dengan rincian standar kompetensi, indikator soal, indikator HOTS, Soal dan Kunci Jawaban.
\end{abstract}

Kata kunci: Keterampilan Berpikir Tingkat Tinggi, Statistika, Taksonomi Bloom.

Copyright (c) 2021 Amalia, Makmuri, Azis

$\bowtie$ Corresponding author:

Email Address: amaliaalfath15@gmail.com

Received 18 Februari 2021, Accepted 29 Juli 2021, Published 20 Agustus 2021

https://doi.org/10.21009/jrpmj.v3i2.22268

\section{INTRODUCTION}

Education is fundamental key for a country. By education, a country can compete with others such as in developing its infrastructures. Likewise, the result of education in Indonesia has not been maximised yet, so education is one of the efforts made by re-evaluating education so that it is able to compete with other countries. In the development of science and technology, learning mathematics as part of national education has an important role because mathematics is a science that underlies other sciences. Therefore, mathematics learning is importantly needed by students starting from elementary school to equip students with the ability to think logically, analysis, systematically, critically, and creatively, also the ability to work cooperatively. These competences are needed for students, so that students can have the ability to obtain, understand, process, and use the information to survive in an ever-changing circumstance, uncertain and competitive situation.

Measuring the goodness level of a test can be seen from its ability to provide a clear description of the success rate of the program or the learning objectives. In order that objectives can be easily evaluated its success, they must have operational character, also have to be classified in a detail form. Bloom et al., has divided the domain of learning objectives consisting of six stages arranged from the 
simplest to the most complex abilities, this is then known as Bloom's taxonomy of learning objectives. However, in order to be able to adopt new developments and findings in education, we may then be able to revise the Bloom's taxonomy. By understanding this classification, the teacher should be able to improve student's learning result by recognizing whether these success indicators have been achieved by specific learning objectives, both concerning to cognitive, affective and psychomotor aspects (Azhar S and Rini, 2013: 1).

The cognitive aspect or domain is a domain that includes mental activity (brain). According to Bloom, all efforts involving the brain are included in the cognitive domain. In the cognitive domain, there are six levels of thinking processes, from the lowest level to the highest. The six levels are knowledge, comprehension, application, analysis, synthesis, and evaluation (Nursalam, 2012: 11).

Based on the bloom's taxonomy, the abilities of students can be classified into two stages, those are the high level and the low level. The low-level abilities consist of knowledge, understanding, and application, while the high-level abilities include analysis, synthesis, evaluation and creativity. Thus, the activity of students in memorizing is including in the low-level abilities. According to the way of thinking, high-order thinking skills are divided into two skills, those are critical thinking and creative thinking. Creative thinking is the ability to generalize by combining, changing or repeating these ideas. The ability of critical thinking is the ability to provide rationalization of something and be able to provide an assessment of something.

Some specialists also distinguish thinking activities into several levels, namely higher order thinking (HOT) and lower order thinking (LOT). Higher order thinking is called a combination of critical, creative and basic knowledge thinking. Thomas, Thorne and Small stated that higher-order thinking puts thinking activity at a higher level than simply stating facts. The concern in higher-order thinking is what will we do with the facts. We have to understand the facts, correlate the facts to one another, categorize, manipulate, use along with them in new situations and apply them in finding new solutions on a problem (Zaenal Arifin, 2009: 23).

The competitive ability of Indonesian students, especially in mathematics, is still very low, compared to students from other countries. This is shown by one of the international studies, namely the PISA test (International Program for Student Assessment) test held by the OECD (Organization for Economic Co-operation and Development). The PISA result (2015) disclosed that Indonesia is ranked 69 out of 76 countries. Meanwhile, the results of the TIMSS (Trends in International Mathematics and Science Study) study show that Indonesian students are ranked 36 out of 49 countries in terms of performing scientific procedures. By these results, Indonesia is still far left behind several countries, Indonesian students are still lacking of ability to answer questions of high-level thinking skills and Indonesian students are nothing else but able to answer questions that are classified as low-level.

To answer questions that measures HOTS, students must have good high-order thinking skills which consist of mathematical problem-solving skills, mathematical comprehension skills, 
mathematical reasoning skills, mathematical connection skills, and mathematical communication skills as a method to practice their high-level thinking skills by delivering specially designed HOTS questions, so that students are indirectly accustomed to developing their thinking process. However, Indonesian students are less practised in solving HOTS questions characteristics. Other problem encountered by the teacher is the lack of characterized questions of the PISA model. For this reason, it is necessary to develop questions with the characteristics of the PISA and TIMSS models, especially those that measure high-order thinking skills (HOTS).

In order that the question demands high-level thinking skill, so each item is always stimulated with the question based on reading sources or materials such as: reading texts, paragraphs, drama texts, fragments of novels / stories / fairy tales, poetry, cases, pictures, graphs, photos, formulas, tables, lists of words / symbols, examples, maps, films, or recorded sound, analysed, evaluated, and created.

Higher Order of Thinking Skill (HOTS) is the ability to think critically, logically, reflectively, metacognitively, and think creatively, which consist higher order thinking skills. The 2013 curriculum also requires learning material to be metacognitive which requires students to be able to predict, design, and estimate. In line with that, the domain of HOTS is analysis which is the ability to think in specifying aspects / elements of a particular context; evaluation is the ability to think in making decisions based on facts / information; and creation is the ability to think in creating ideas. These abilities are top-level thinking skills in the latest revised Bloom's taxonomy by Anderson and Krathwohl as shown below. (Retno Utari, 2013).

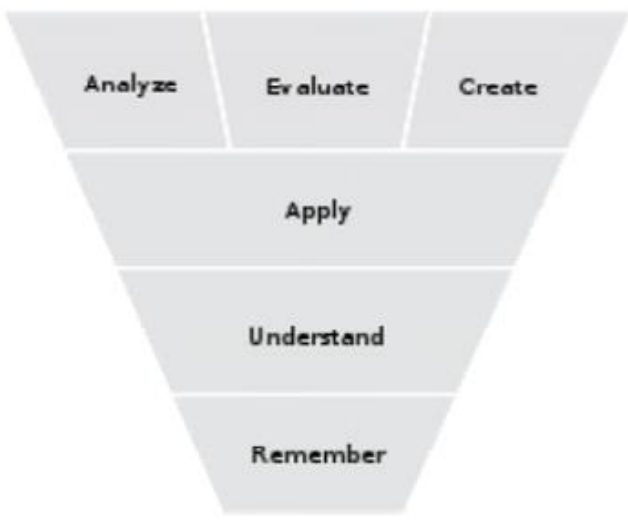

Higher order thinking skills are the ability to understand and find solutions to a problem in a variety way, different from what is usually do (divergent), from a different point of view according to the abilities of each student (Nunung, 2015: 3).

Dewanto (in Kus Andini, 2017: 40), states that higher-order thinking skills are a capacity based on the information provided, with a critical attitude to evaluate, have metacognitive awareness and have problem solving abilities.

Referring to the definition from Wikipedia Indonesia, higher-order thinking is a concept of educational reformation that requires learning methods based on a taxonomy learning, for example Bloom's taxonomy which involves analysis, synthesis and evaluation skills. According to Bloom, 
education should focus on competence (mastery subject) and the achievement of higher order thinking results (Nunung, Husen and Jenuri, 2015: 3).

Based on the description above, it can be concluded that the ability to think at a higher level (higher order thinking) is the ability to practice students to manipulate information and ideas and connect the learning with everyday life that has never been taught before in order to explain, interpret and draw conclusions, in other words, students can apply the knowledge and skills from the concepts that have been learned.

There are several ways that can be used as guidelines by the writers to write questions that require higher-order thinking, the material to be asked is measured by behaviour in accordance with Bloom's cognitive domain at the level of analysis, evaluation and creation, each question consists of a basic question (stimulus) and questions measuring critical thinking skills.

Assessing or measuring is not just to memorize a number of information, but more on how to process a number of information to get a solution to the problem. Assess or measure more complex skills such as critical thinking and stimulate students to interpret, analyse or even be able to manipulate previous information so that it is not monotonous. Higher-order thinking shows understanding of information and reasoning, not just remembering information. We do not test a memory, so it is sometimes necessary to provide the information needed to answer questions and students demonstrate understanding of ideas and information and / or manipulate or use that information.

\section{KETERAMPILAN BERPIKIR TINGKAT TINGGI}

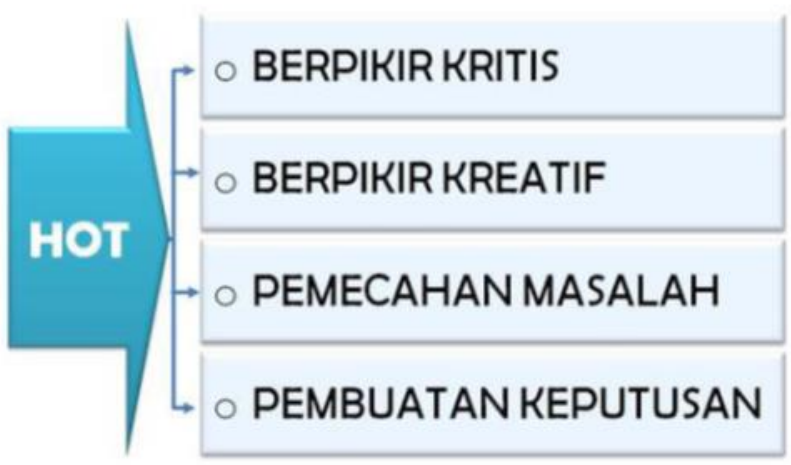

The HOTS skills in Bloom's taxonomy include the three highest levels, those are analysis, evaluation and creation. For intermediate level students, not all skills can be practiced by solving problems, but we can choose them which are in accordance with the level of thinking of these students and design them into questions that encourage higher order thinking students.

The teaching and learning process in schools needs to be directed to further hone students' higher order thinking skills. One of the solutions that are regarded as being able to optimize higherorder thinking skills in mathematics learning is through problem solving (Kusumaningrum, 2012). Problem-solving abilities are interrelated with the ability to think critically and creatively, because in 
the teaching and learning process is not directly learning the material, but rather, to think critically and creatively to solve a problem.

\section{METHODS}

This study aims to analyse the questions of high order thinking skills in the Statistics chapter in the 2013 Curriculum Mathematics textbook which are measured based on indicators of cognitive levels in Bloom's taxonomy.

This study uses a qualitative descriptive approach, and the type of research used is library research, which is collecting data or scientific papers related to the object of research or collecting library data, Mustika Zed (2014). Or a study that is carried out to solve a problem which basically rests on a critical and in-depth study of the relevant library materials. In theory exploration, researchers will collect as much information as possible from related literature. Literature sources can be obtained from books, journals, magazines, research results and other appropriate sources. When the relevant literature has been obtained, it is immediately compiled regularly to use in research. Therefore, literature study includes general processes such as systematically identifying theories, finding literature and analysing documents that contain information related to the research topic. The study in the research focuses more on the analysis of high order thinking skills questions in the Statistics chapter in the 2013 Curriculum Mathematics textbook which is measured based on cognitive level indicators in Bloom's taxonomy.

\section{RESULTS AND DISCUSSION}

Based on the theoretical review, In order that the question demands high-level thinking skill, so each item is always stimulated with the question based on reading sources or materials such as: reading texts, paragraphs, drama texts, fragments of novels / stories / fairy tales, poetry, cases, pictures, graphs, photos, formulas, tables, lists of words / symbols, examples, maps, films, or recorded sound, analysed, evaluated, and created.

A method that can be used as a guideline by question writers to write items that require higherorder thinking, is the material to be asked is measured by behaviour in accordance with Bloom's cognitive domain at the level of analysis, evaluation and creation, each question consists of a basic question (stimulus) and question that measures critical thinking skills. According to (Saido et al, 2018) in improving students' higher order thinking skills, a strategy is needed to increase student HOTS, by problem solving activities.

Here are some examples of HOTS questions on Statistics topic for XII grade students which are oriented towards problem solving.

\section{Example 1.}

\section{Grade : XII}




\section{Topic : Statistics}

\section{Basic Competency :}

1.2 Determine and analyse the size of concentration and distribution of data presented in frequency distribution tables and histograms

4.2 Solving problems related to the data presentation as a result of measurement and enumeration in frequency distribution tables and histograms

\section{HOTS indicators :}

\begin{tabular}{|l|l|}
\hline \multicolumn{1}{|c|}{ Indicator } & \multicolumn{1}{c|}{ HOTS Question } \\
\hline $\begin{array}{l}\text { The time difference between men and } \\
\text { women }\end{array}$ & Stated in a table (evaluate) \\
\hline Running time Men and women & Stated explicitly in a table (analyse) \\
\hline Material & $\begin{array}{l}\text { Combine the statistics concept and logical thinking } \\
\text { (create })\end{array}$ \\
\hline Kinds of Question & Stated implicitly by the possible result (evaluate) \\
\hline
\end{tabular}

Questions Indicator: Determines the possible values from reading the data in the table.

\section{Question:}

The following table shows the running times in minutes and seconds for the gold medal winners at the 2008 Olympics in the $100 \mathrm{~m}, 200 \mathrm{~m}, 400 \mathrm{~m}$ and $800 \mathrm{~m}$ races.

\begin{tabular}{|c|c|c|}
\hline Lomba & Pria & Wanita \\
\hline $100 \mathrm{~m}$ & 9,69 & 10,78 \\
\hline $200 \mathrm{~m}$ & 19,30 & 21,74 \\
\hline $400 \mathrm{~m}$ & 43,75 & 49,62 \\
\hline $800 \mathrm{~m}$ & $1: 44,65$ & $?$ \\
\hline
\end{tabular}

Which of the following is the most likely run time for the gold medal winner for the women's $800 \mathrm{~m}$ race?
A. $1: 00,18$
B. $1: 20,43$
C. $1: 48,02$
D. $1: 54.87$

The Discussion of the problem is as follows: 
From the table below, the time for a women's race at $800 \mathrm{~m}$ is likely to be longer than a men's race at $800 \mathrm{~m}$.

\begin{tabular}{|c|c|c|c|}
\hline Lomba & Pria & Wanita & Beda Waktu \\
\hline $100 \mathrm{~m}$ & 9,69 detik & 10,78 detik & 1,09 detik \\
\hline $200 \mathrm{~m}$ & 19,30 detik & 21,74 detik & 2,44 detik \\
\hline $400 \mathrm{~m}$ & 43,75 detik & 49,62 detik & 5,87 detik \\
\hline $800 \mathrm{~m}$ & 1 menit 44,65 detik & $?$ & \\
\hline
\end{tabular}

The farther the race distance, the greater the time difference, for the difference in running 800 $\mathrm{m}$, maybe more than 5.87 seconds, because difference for $400 \mathrm{~m}$ is that large.

So if you look at the possible answer choices, the ones that have a difference of above 5.87 seconds, from the $800 \mathrm{~m}$ time result, the time for the $800 \mathrm{~m}$ women's race is:

waktu > $(1: 44,65+5,87)$

Waktu $>1: 50,52$

\section{Answer D. 1:54.87}

\section{Example 2.}

\section{Grade: XII}

Topic: Statistic

\section{Basic Competency:}

3.2.1. Describing data in tables or diagrams / plots that are in accordance with the information you want to communicate.

\section{HOTS Indicator:}

\begin{tabular}{|l|l|}
\hline \multicolumn{1}{|c|}{ Indicator } & \multicolumn{1}{c|}{ HOTS Question } \\
\hline Number of Phone Calls & Stated in a table (evaluate) \\
\hline Daily phone calls & Stated implicitly in a table (analyse) \\
\hline Material & Combine the statistics concept and logical thinking (create) \\
\hline Kind of Question & $\begin{array}{l}\text { Stated implicitly by the number of days and telephone calls } \\
\text { (evaluate) }\end{array}$ \\
\hline
\end{tabular}

\section{Question Indicator:}


Presented in a dual bar diagram of the record of the number of incoming and outgoing telephone calls per day in 9 days. Students can read the data on multiple bar charts.

\section{Question:}

A telecommunication company is conducting a survey to see the activities of its customers in making phone calls. One day Ratna got an assignment from the telecommunications company to record the number of phone calls he made in a period of consecutive days. The results of Ratna's recording are presented in the graph below:

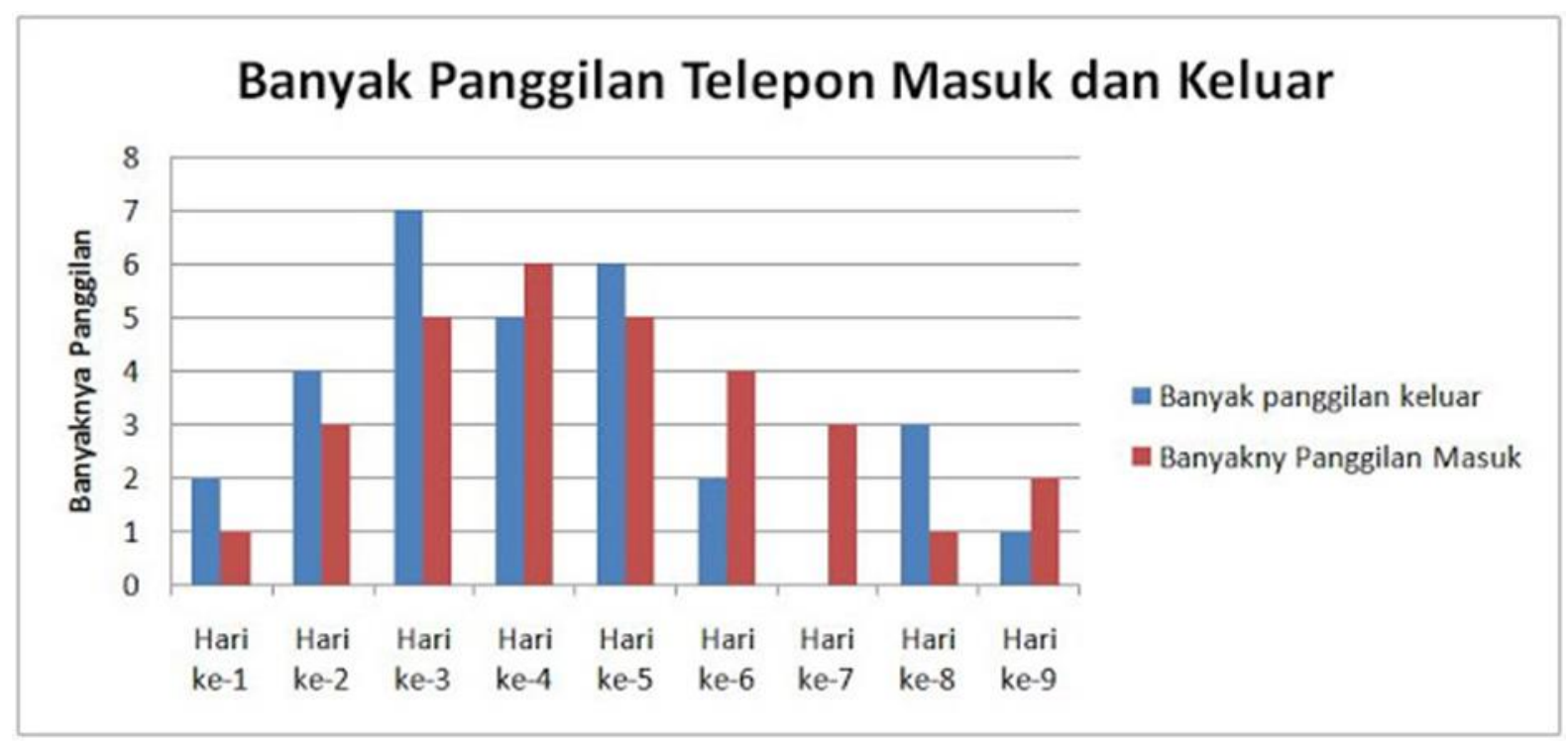

\section{The questions are:}

1. Ratna got the most outgoing calls on the following day...
a. $1^{\text {st }}$ day
b. $2^{\text {nd }}$ day
c. $3^{\text {rd }}$ day
d. $4^{\text {th }}$ day

2. Ratna only made incoming calls on the day of...

3. Ratna received more incoming calls than outgoing calls on the day of...

\section{The Discussion of the problem is as follows:}

1. Regarding to the graph, outgoing calls are the blue bar graph, and the blue bar graph is the highest on the 3rd day, then the highest outgoing calls are on the 3rd day.

2. Only incoming calls means, Ratna does not make outgoing calls, seen in the graph that there are no outgoing calls is in the blue graph means that there is no score is on Day 7

3. Ratna received more incoming calls means, on the red graph the position is higher than the blue graph on the same day, seen on the red graph is higher than the blue is on Day 4, 6, 7 and 9 


\section{Example 3.}

\section{Grade: XII}

Topic: Statistic

\section{Basic Competency:}

3.1 Determine the average, median, and single data mode and its interpretation

\section{HOTS Indicator:}

\begin{tabular}{|l|l|}
\hline \multicolumn{1}{|c|}{ Indicator } & \multicolumn{1}{c|}{ HOTS Question } \\
\hline Average value and range & Stated explicitly (evaluate) \\
\hline Lowest and highest scores & Stated implicitly by the results of new average (analyse) \\
\hline Material & Determines the lowest and highest scores (create) \\
\hline Kind of Question & Stated implicitly by the lowest score (evaluate) \\
\hline
\end{tabular}

\section{Question Indicator:}

Presented the average data, and the range, students can determine the lowest score after eliminating the lowest highest score.

\section{Question:}

In a class there are 22 students, the mathematical average score is 5 and the range is 4 . If a student with the lowest score and a student with the highest score is not included, then the average score changes to 4.9. The lowest students' score is...

\section{The Discussion of the problem is as follows:}

Described:

Number of students $=\mathrm{n}=22$

Average score $=x=5$

Total score $=n \cdot x=22 \times 5=110$

If the lowest and the highest score are excluded, so:

Number of students $=\mathrm{n}=20$

Average score $=\mathrm{x}=4,9$

Total score $=n \cdot x=20 \times 4,9=98$

The number of the lowest and highest score is the difference of total score.

$=110-98$

$=12$

Because the range is $=4$, so the highest score minus the lowest score is $=4$. 


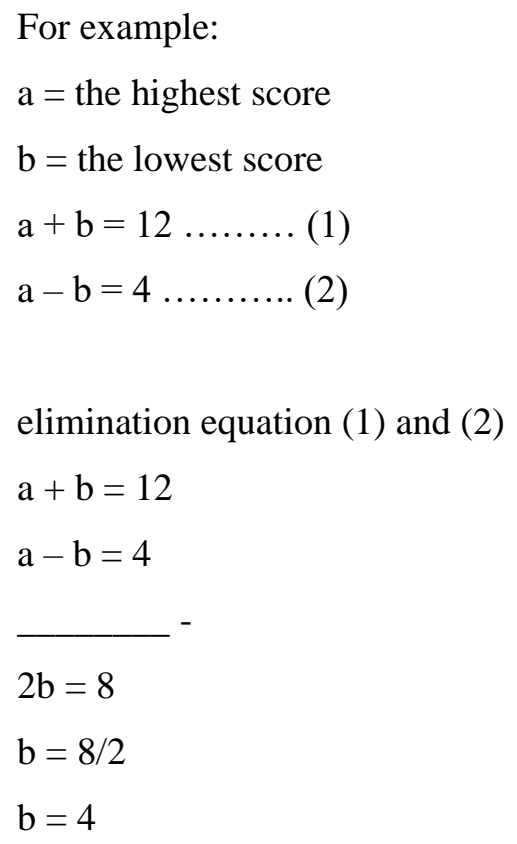

So The lowest students' score is 4

\section{CONCLUSION}

Based on the results and discussion, it is concluded that creating HOTS questions in mathematics learning is important. This aims to improve students' abilities in analysing, evaluating, and being creative, so that students have critical power and creativity to solve problems in everyday life.

The teaching and learning process in schools needs to be directed to further hone students' higher order thinking skills. One of the solutions that is regarded as being able to optimize higher order thinking skills in mathematics is learning mathematics through problem solving.

Creating questions is based on problem solving with details of competency standards, question indicators, HOTS indicators, Questions and Answer Keys.

\section{THANK-YOU NOTE}

The preparation of this research cannot be separated from prayers, support, direction, guidance, assistance, and the participation of various parties. Therefore, on this occasion the author would like to thank:

1. Mr. Dr. Makmuri, M.Si., as Supporting Lecturer 1, who have helped and provided direction in this research.

2. Mr. Tian Abdul Aziz, Ph.D., as Supporting Lecturer 1, who have provided direction and motivation in completing this research.

3. Class friends who have helped and motivated during the research. 


\section{REFERENCE}

Arifin, Zaenal. Evaluasi Pembelajaran, Bandung: PT Remaja Rosdakarya, 2009.

Fadillah, Syarifa. "Kemampuan Pemecahan Masalah Matematis DalamPembelajaran Matematika." Prosiding Seminar Nasionsal Pendidikan dan Penerapan MIPA Fakultas MIPA (Mei 2009): h. 544.

Faisal, Rizki. "Pengembangan Paket Tes Kemampuan Berpikir Tingkat Tinggi (Higher Order Thinking Skill) Berdasarkan Taksonomi Bloom pada Materi Matematika Kelas VII SMP.” (Skripsi Sarjana, Fakultas Keguruan dan Ilmu Pendidikan Universitas Jember, Jember, 2015)..

Fitriani, Nunung." The Influence Of Hots Through SPPKB Model In Mathematics Learning To Students' Creative Thinking Ability.” Juni (2015): h. 3.

Hamzah, Ali dan Muhlisrairi. Perencanaan dan Strategi Pembelajaran Matematika. Jakarta: Raja Wali Pers, 2014.

Jihad, Asep dan Abdul Haris. Evaluasi Pembelajara. Yogyakarta: Multi Pressindo, 2012.

Kemendikbud, (2018). Modul Penyusunan Higher Order Thinking Skill (HOTS). Jakarta: Direktort Jenderal Pendidikan Dasar dan Menengah Departeman Pendidikan dan Kebudayaan.

Kemendiknas. 2010. Bahan pelatihan metodologi belajar mengajar aktif. Jakarta. Balitbang.

Kementrian Pendidikan dan Kebudayaan. "Matematika Studi dan Pengajaran". Jakarta: Pusat Kurikulum dan Perbukuan, 2014.

Kurniawan, Deni. Pembelajaran Tematik Terpadu. Bandung: Alfabeta, 2014.

Kus Andini Purbaningrum, Kemampuan Berpikir Tingkat Tinggi Siswa Smp Dalam Pemecahan Masalah Matematika Ditinjau Dari Gaya Belajar, JPPM (Jurnal Penelitian dan Pembelajaran Matematika). Jurusan Pendidikan Matematika FKIP Universitas Sultan Ageng Tirtayasa. Banten. 2017

Kusumaningrum, et al." Mengoptimalkan Kemampuan Berpikir Matematika Melalui Pemecahan Masalah Matematika.“Jurnal (2012).

Lestari, Eka Kurnia dan Mokhammad Ridwan Yudhanegara. "Penelitian pendidikan Matematika". Bandung: PT. Refika Aditama, 2015.

Mardapi, Djemari. Teknik Penyusunan Instrumen Tes dan Non Tes. Jogjakarta:Mitra Cendekia Press. 2008.

Mawaddah, Siti. "Kemampuan Pemecahan Masalah Matematis Siswa Pembelajaran dengan Menggunakan Model Pembelajaran Generatif (Generative Learning) di SMP”. Jurnal Pendidikan Matematika 3, no. 2 (2015): h. 167.

Mustamin, Sitti Hamsiah. Psikologi Pembelajaran Matematika. Makassar: Alauddin University Press, 2013.

Mustika Zed, Metode Penelitian Kepustakaan, Yayasan piustaka obor Indonesia, 2014, Jakarta.

Nisa, N. A. K., Widyastuti, R., \& Hamid, A. (2018). Pengembangan Instrumen Assessment Higher Order Thinking Skill (HOTS) pada Lembar Kerja Peserta Didik Kelas VII SMP. In Prosiding Seminar Nasional Matematika dan Pendidikan Matematika (Vol. 1, No. 2, pp. 543-556).

Nopriyanti, Tika Dwi. "Pengembangan Soal untuk Mengukur Kemampuan Koneksi Matematis Siswa." 
Prosiding, Universitas PGRI Palembang, (2015).

Nunung Fitriani Dan Husen Windayana Dan Jenuri. 2015. “ The Influence Of Hots Through Sppkb Model In Mathematics Learning To Students' Creative Thinking Ability"

Nursalam. Pengukuran dalam Pendidikan. Makassar: Alauddin University Press, 2012.

Rahayu, Tuti, Purwoko, dan Zulkardi, " Pengembangan Instrumen Penilaian Dalam Pendidikan Matematika Realistik Indonesia (PMRI) di SMP 17 Negeri Palembang”.Jurnal Pendidikan Matematika 2, no. 2 (2008): h. 2.

Retno Utari. Taksonomi Bloom, Apa dan Bagaimana Menggunakannya? Pusdiklat KNPK.

Rofiah, Emi, Nonoh Siti Aminah, dan Elvin Yusliana Ekawati. "Penyusunan Instrumen Tes Kemampuan Berpikir Tingkat Tinggi Fisika Pada Siswa Smp.” Jurnal Pendidikan Fisika 1, no.2 (2013) h. 17.

Rosmawati, Sri Elniati, dan Dewi Murni.'Kemampuan Pemecahan Masalah dan Lembar Kegiatan Siswa Berbasis Problem Solving." Jurnal Pendidikan Matematika 1, no. 1 (2012): h. 80.

Saido, G. M., Siraj, S., Nordin, A. B. B., \& Al_Amedy, O. S. (2018). Higher order thinking skills among secondary school students in science learning. MOJES: Malaysian Online Journal of Educational Sciences, 3(3), 13-20.

Sudjana, Nana . Penilaian Hasil Proses Belajar Mengajar. Bandung: PT. Remaja Rodakarya, 2009.

Sudjono, Anas. Pengantar Evaluasi Pendidikan. Jakarta: PT RajaGrafindo Persada, 2003.

Sukardi. Metodologi Penelitian Pendidikan. Cet. XIV; Yogyakarta: Bumi Aksara, 2014.

Sukmadinata, Nana Syaodih. "Metode Penelitian Pendidikan". Bandung: PT. Remaja Rosdakarya, 2013.

Sumartini, Tina Sri. "Peningkatan Kemampuan Pemecahan Masalah Matematis Siswa Melalui Pembelajaran Berbasis Masalah.” Jurnal Pendidikan Matematika 8, no 3 (2016): h. 14.

Suryabrata, Sumadi. Psikologi Pendidikan. Rajawali Perss, 2013.

Suwarto. "Pengembangan Tes Diagnostik dalam Pembelajaran”. Yogyakarta: Pustaka Pelajar, 2013.

Syarifuddin, Azhar dan Rini Setianingsih. "Pengembangan Instrumen Bloom Digital Assessment (BDA) Pada Materi Pokok Lingkaran dikelas VIII." Jurnal (2013): h. 1.

Uno, Hamzah B. Model Pembelajaran Menciptakan Proses Belajar Mengajar yang Kreatif dan Efektif. Jakarta: PT Bumi Aksara 2012.

How to cite : Amalia, L., Makmuri., \& Aziz, T. A., 2021. Analysis of Mathematic High Order Thinking Skills (HOTS) Problems Based on Cognitive Level Indicators on Bloom Taxonomy. Jurnal Riset Pendidikan Matematika Jakarta. 3(2). 64-75. https://doi.org/10.21009/jrpmj.v3i2.22268

To link to this article: $\underline{\text { htps://doi.org/10.21009/jrpmj.v3i2.22268 }}$ 